\title{
Risks During the Production and use of the thin Steel Sheets as one of the Most Ecological Materials in Packaging Technology
}

\author{
Emil Spišák ${ }^{1, *}$ and Janka Majerníková ${ }^{1}$ \\ 1 Department of Mechanical Technology and Materials, Faculty of Mechanical Engineering, Technical University of Košice, Košice, Slovakia
}

\begin{abstract}
Thin steel sheets, which surface is processed against corrosion with various coatings, are still being used nowadays for the production of various packages, mainly for the long-term storing of materials. These packages are required to be reliably functioning while not contaminating the inner content for the whole time. In practice, we often encounter the opinion that the packages from thin steel sheets have been in recent years substituted with the packages made from non-metal materials, mainly from plastic materials. However, from the recent statistical evaluation it is evident that the packages from thin steel sheets play a significant role in the production of packages. This contribution describes changes in the production of steel sheets during recent years and the influence of these changes on the final properties of thin sheets. Contribution also presents the examples of disruption of such packages from thin steel sheets and the analysis of such disruptions.
\end{abstract}

Keywords: thin steel sheet; package; corrosion; coating.

\section{Introduction}

Thin steel sheets have been used for the production of packages for more than 100 years. Production of packages, as well as the production of steel sheets used for the production of packages, has considerably changed over this period of time. Until the second half of 1980s, most of the steel worldwide was produced by a traditional billet casting method. Billets were consequently divided and rolled in horizontal and vertical rolls (so called slabbing) where the slabs were produced. Slabs were after that processed by hot and cold rolling. Steel is currently produced by continual casting in various ways. Continuous casting of steel brought considerably higher purity, more balanced configuration of elements contained in steel and thus more balanced properties of the products made of such steel. During the production of thin packaging sheets from such steel it is possible to reach better mechanical properties of sheets and that creates an ability to produce sheets of a lower thickness. Thickness of the packaging sheets back in 1980 s varied from $0.24 \mathrm{~mm}-0.36 \mathrm{~mm}$, nowadays, the bottom bound of thickness is decreased down to $0.13 \mathrm{~mm}$. This fact leads to the conclusion that from a particular amount of steel it is now possible to produce twice as many packages as it was possible in the past. Fig. 1 presents a percentage representation of application of the packaging materials in the industries.

\section{The necessity, opportunities and limitations of reuse of waste water}

Production process of the thin packaging sheet has gone through some considerable changes over recent years. Production process has incorporated several new technologies such as continuous casting that provides homogeneity of chemical properties, higher purity, homogenous structure and improvement of the

* Corresponding author: Emil Spišák, E-mail:emil.spisak@tuke.sk 


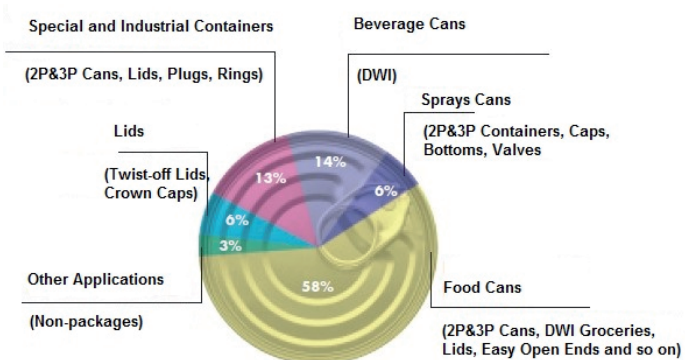

Fig. 1: Analysis of the application of thin packaging sheets in the branches of industry [1].

properties of a final product [2]. Continual annealing is a new method with the built-in artificial aging that enables a production of practically non-aging material, appropriate for the technology of drawing [3].

Another new element is the incorporation of the second reduction (DR-double reduction), which provides higher hardness and strength than the only once reduced material has. Final material after second reduction is light steel sheet of the thickness $0.13 \mathrm{~mm} \div 0.18 \mathrm{~mm}$, which represents the decrease of weight of the final products even by $40 \%$. What is also important in the case of such thin sheets is to improve properties of the protection layers in terms of corrosion resistance. Mass of the tin coating in this case ranges from 1.0/1.1 $\div 1.4 / 2.0 \mathrm{~g} / \mathrm{m}^{2}$ [3].

The largest producer of tin-coated packaging sheet in Slovakia is U.S. Steel, s. r. o. Košice, which produces electrolytic tin-coated packaging sheets of the thickness $0.13 \mathrm{~mm} \div 0.30 \mathrm{~mm}$. Their production has gone through considerable changes in the last 15 years. The main change was a switch from the casting of rimming steel into the cast-iron moulds to the continuous casting of killed steel (deoxidized with aluminium) into the slabs on the continuous casting machine. Warm broadband track and the picking lines in the cold roll mill were modernized. Continuous annealing line, coil preparation line and electrolytic tin-coating line has also gone through a large reconstruction.

All these changes took part in bringing the higher quality of the produced tin-coated packaging sheet [3]. Production process of thin packaging sheets, apart from above mentioned changes in technology, consists of other parts of production line as well, cleaning line and cleaning section, distribution, preparation before tin-coating process and tin-coating process itself.

\subsection{Division of thin packaging sheets}

Nowadays, the most common tests used to analyse basic mechanical properties needed for the division of the thin packaging sheets are mainly a tensile test and a hardness test. Tensile test defines basic mechanical properties of the thin packaging sheets - yield strength, tensile stress and elongation. Norms standardize the hardness test according to Rockwell. These two tests and the mechanical properties obtained by them represent basic criteria for the evaluation and the division of the sheets into the individual categories.

Rockwell hardness test is used mainly for once reduced tin-coated steel sheets that were cold rolled and consequently processed by recrystallization annealing. Uniaxial tensile test is recommended to be used for the evaluation of double reduced tincoated sheets, where recrystallization annealing is followed by the second reduction of $15 \div 40 \%$. Based on the above mentioned tests, the thin packaging sheets are divided into the quality groups (called "tempers" by the manufacturers and processors, T1T5 according to EN 10203, or T50, T52, T57, T61, T65 according to ASTM 623 M - 92 and JIS G 3303). Tab. 1 shows the division of packaging sheets according to various norms and criteria. [2]

Tab. 1: Division of packaging sheets according to hardness [2].

\begin{tabular}{|l|l|l|l|}
\hline $\begin{array}{l}\text { Temper according } \\
\text { to EN 10203 }\end{array}$ & $\begin{array}{l}\text { Temper according } \\
\text { to ASTM, JIS }\end{array}$ & $\begin{array}{l}\text { Nominal value } \\
\text { HR30Tm }\end{array}$ & $\begin{array}{l}\text { Acceptable } \\
\text { deviation }\end{array}$ \\
\hline T1 & T50 & 52 & \pm 4 \\
\hline T2 & T52 & 52 & \pm 4 \\
\hline T3 & T57 & 57 & \pm 4 \\
\hline T4 & T61 & 61 & \pm 4 \\
\hline T5 & T65 & 65 & \pm 4 \\
\hline
\end{tabular}

This classification of packaging sheets is based on the hardness test HR30 Tm and it does not contain basic mechanical and plastic properties of materials, which are often necessary for the designing of the technological processes of thin packaging sheets processing. Dominant producers of thin packaging sheets from European countries united into the union SEFL. In 1991, they all accepted recommendations for the packaging sheets labelling, which defines the mechanical properties of the thin packaging sheets. Overview of these mechanical properties of the thin packaging sheets is presented in the Tab. 2 [6]. 
Tab. 2: Overview of the mechanical properties of simply and double reduced tin-coated packaging sheet [6].

\begin{tabular}{|c|c|c|c|c|c|c|}
\hline \multicolumn{7}{|c|}{ Simply reduced packaging sheets } \\
\hline \multicolumn{2}{|l|}{ quality according to } & \multicolumn{5}{|c|}{ hardness HR30 Tm for the nominal thickness } \\
\hline \multirow[t]{2}{*}{$\begin{array}{l}\text { EN 10205/91 } \\
\text { EN 10203/91 }\end{array}$} & EN 10202/01 & \multicolumn{2}{|c|}{$\mathrm{a} \leq 0.21 \mathrm{~mm}$} & \multicolumn{2}{|c|}{$a>0.21 \leq 0.28 \mathrm{~mm}$} & $a>0.28 \mathrm{~mm}$ \\
\hline & TS260 & \multicolumn{2}{|l|}{$52-60$} & \multicolumn{2}{|l|}{$51-59$} & $50-58$ \\
\hline T57 & TS275 & \multicolumn{2}{|l|}{$54-62$} & \multicolumn{2}{|l|}{$53-61$} & $52-60$ \\
\hline T61 & TH415 & \multicolumn{2}{|l|}{$58-66$} & \multicolumn{2}{|l|}{$57-65$} & $56-64$ \\
\hline \multirow[t]{8}{*}{ T 65} & TH435 & \multicolumn{2}{|l|}{$61-69$} & \multicolumn{2}{|l|}{$61-69$} & $60-68$ \\
\hline & & \multicolumn{5}{|c|}{ mechanical properties (EN 10202/01) } \\
\hline & & \multicolumn{2}{|l|}{$\mathrm{R}_{\mathrm{p}} 0.2 \mathrm{MPa}{ }^{11}$} & \multicolumn{3}{|l|}{$\mathrm{R}_{\mathrm{m}} \mathrm{MPa}{ }^{11}$} \\
\hline & & range & nominal value & \multicolumn{2}{|l|}{ range } & nominal value \\
\hline & TS260 & $210-310$ & 260 & \multicolumn{2}{|l|}{$310-410$} & 360 \\
\hline & TS275 & $225-325$ & 275 & \multicolumn{2}{|l|}{$325-425$} & 375 \\
\hline & TH415 & $365-465$ & 415 & \multicolumn{2}{|l|}{$385-485$} & 435 \\
\hline & TH435 & $380-480$ & 430 & \multicolumn{2}{|l|}{$410-510$} & 460 \\
\hline \multicolumn{7}{|c|}{ Double reduced packaging sheets } \\
\hline \multicolumn{2}{|l|}{ quality according to } & \multicolumn{2}{|l|}{$\mathrm{R}_{\mathrm{p}} 0.2 \mathrm{MPa}{ }^{11}$} & \multicolumn{2}{|l|}{$\mathrm{R}_{\mathrm{m}} \mathrm{MPa}{ }^{1)}$} & \multirow{2}{*}{$\begin{array}{l}\text { hardness HR } 30 \mathrm{Tm} \\
\text { EN 10203/91 }\end{array}$} \\
\hline \multirow[t]{3}{*}{$\begin{array}{l}\text { EN 10203/91 } \\
\text { EN 10205/91 }\end{array}$} & EN 10202/01 & range & nominal value & range & nominal value & \\
\hline & TS550 & $500-600$ & 550 & $525-625$ & 575 & \\
\hline & TH520 & $470-570$ & 520 & $490-590$ & 540 & \\
\hline \multirow[t]{2}{*}{ DR 550} & TH550 & $500-600$ & $5503)$ & $520-620$ & 570 & $70-76$ \\
\hline & TH580 & $530-630$ & 580 & $540-640$ & 590 & \\
\hline DR 620 & TH620 & $570-670$ & $6203)$ & $575-675$ & 625 & $73-79$ \\
\hline \multicolumn{7}{|c|}{$\begin{array}{l}\text { 1) samples in the direction of rolling } \\
\text { 2) according to EN 10202/01 } \\
\text { 3) according to the norm EN } 10203 / 91 \text { range } \pm 70 \mathrm{MPa}\end{array}$} \\
\hline
\end{tabular}

Properties of the packaging sheets are dependent on chemical composition of the steel they are made from, but also dependent on the chosen production method of the steel sheets. Mechanical and plastic properties are influenced by the method of hot rolling, finish rolling and coiling temperatures, method of cold rolling, recrystallization annealing, second reduction size and method of tin-coating.

\section{Use of packaging sheets}

Up to $90 \%$ of tin-coated sheets, which are currently produced in the world, are produced for the food industry, for the production of packages, cans, ends, lids and other products (Fig. 2). Rest of the sheets is used in the automobile industry, computer industry, telecommunication and other branches of industry.

Producers of steel sheets have accepted and ad- opted standard naming, labelling and categorization of thin packaging sheets according to ASTM, which is presented in the Tab. 3.

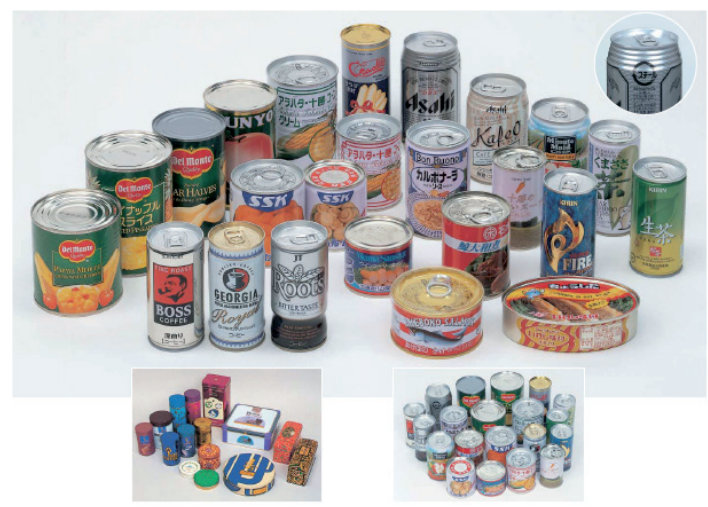

Fig. 2: Examples of the products from packaging sheet. 
Tab. 3: Classification of packaging sheets according to the surface [9].

\begin{tabular}{|c|c|c|}
\hline \multicolumn{2}{|c|}{ Classification of packaging sheets } & Use of packaging sheets (Tab. 4 and Tab. 5) \\
\hline \multirow[b]{2}{*}{ Black Plate } & Simply rolled black plate (CR BP) - ASTM A625/A625M & \multirow{2}{*}{$\begin{array}{l}\text { Used for the production of transport con- } \\
\text { tainers, lids, information signs and for the } \\
\text { coating process. }\end{array}$} \\
\hline & $\begin{array}{l}\text { Double reduced black plate (2 CR BP) - ASTM A650/ } \\
\text { A650M }\end{array}$ & \\
\hline \multirow{2}{*}{ Electrolytic Tin Coated } & $\begin{array}{l}\text { Simply rolled electrolytic tin coated sheet (CR ETP) } \\
\text {-ASTM A624/A624M }\end{array}$ & \multirow{2}{*}{$\begin{array}{l}\text { Used for the production of food packages, } \\
\text { cans, lids, crown caps and other products } \\
\text { (Fig. 2) }\end{array}$} \\
\hline & $\begin{array}{l}\text { Double reduced electrolytic tin coated sheet (2 CR ETP) } \\
\text {-ASTMA626/A626M }\end{array}$ & \\
\hline \multirow{2}{*}{ Electrolytic Chromium Coated } & $\begin{array}{l}\text { Simply rolled electrolytic chromium black sheet } \\
\text { (1 CR ECCS) }\end{array}$ & \multirow{2}{*}{$\begin{array}{l}\text { Used for the production of cans, food can } \\
\text { end, crown caps, vacuum caps for the } \\
\text { protection of glass bottles and other } \\
\text { products. }\end{array}$} \\
\hline & $\begin{array}{l}\text { Double reduced electrolytic chromium black plate } \\
\text { (2 CR ECCS) }\end{array}$ & \\
\hline
\end{tabular}

In the Tab. 4 and Tab. 5, there presented examples of the use of individual types of sheets according to their thickness and the production process. Tab. 4 presents the examples of use of the simply rolled packaging sheets; Tab. 5 shows the examples of use of the double reduced packaging sheets.

Tab. 4: Use of the simply rolled sheets (SR) according to the thickness [9].

\begin{tabular}{|l|l|}
\hline Thickness $[\mathrm{mm}]$ & Lids and top/bottom parts of cans \\
\hline 0.17 & Instant coffee cans, cooking oil cans, sweets \\
\hline 0.18 & $\begin{array}{l}\text { Instant coffee cans, baby food, cooking oil, } \\
\text { sweets }\end{array}$ \\
\hline 0.19 & Tall cans for food and sweets, 15 kg food cans \\
\hline 0.21 & $15 \mathrm{~kg}$ food cans \\
\hline 0.22 & Cans for the cooking ingredients \\
\hline
\end{tabular}

Tab. 5: Use of the double reduced sheets (DR) according to the thickness [9].

\begin{tabular}{|l|l|}
\hline Thickness $[\mathrm{mm}]$ & Lids and top/bottom parts of cans \\
\hline 0.19 & $\begin{array}{l}\text { Lids for the welded cans, baby food cans, } \\
\text { condensed milk cans }\end{array}$ \\
\hline 0.20 & $\begin{array}{l}\text { Battery wrappers, welded food cans and } \\
\text { other parts }\end{array}$ \\
\hline 0.21 & $1 \mathrm{~kg}$ paint cans \\
\hline 0.22 & $\begin{array}{l}2 \mathrm{~kg} \text { containers, lids for } 2 \text { kg containers, } 4 \\
\text { liters rimmed paint cans }\end{array}$ \\
\hline 0.24 & $\begin{array}{l}\text { Crown caps, containers for lubrication oils } \\
\text { and pesticides, 4 liters paint cans }\end{array}$ \\
\hline 0.25 & $\begin{array}{l}\text { Crown caps, containers for lubrication oils } \\
\text { and greases, 5 liters canisters for petroleum } \\
\text { products }\end{array}$ \\
\hline 0.26 & Rings and lids for 4 litres paint cans \\
\hline 0.28 & 15 kg containers - top/bottom part \\
\hline
\end{tabular}

Currently in the field of packaging sheets processing, we can encounter following production technologies, presented in the Tab. 6.

Tab. 6: Production technologies of the products made from packaging sheets.

\begin{tabular}{|l|l|}
\hline Products from packaging sheets & Production technology \\
\hline 3PC - Three - Pieces Cans & $\begin{array}{l}\text { drawn - can ends, cover } \\
\text { according to the shape - by } \\
\text { curling or bending (circular } \\
\text { - by curling, square - by cur- } \\
\text { ling + shaping or bending) }\end{array}$ \\
\hline 2PC - Two - Pieces Cans & DRD - Deep Drawn Cans \\
\cline { 2 - 2 } & $\begin{array}{l}\text { DWl - Drawn \& Wall Ironed } \\
\text { Cans }\end{array}$ \\
\hline \multirow{5}{*}{ lids and ends } & $\begin{array}{l}\text { OTE - Open Top Ends and } \\
\text { Lids }\end{array}$ \\
\cline { 2 - 3 } & EOE - Easy Open Ends \\
\cline { 2 - 3 } & Bottle Caps \\
\cline { 2 - 3 } & EPE - Easy Peel Ends \\
\cline { 2 - 3 } & PE - Pourable Ends \\
\cline { 2 - 3 } & TOE - Twist Off Ends \\
\hline
\end{tabular}

\subsection{Problems during use of packages from thin steel sheets}

Thin steel sheets are currently processed mainly for the production of cans of different types and shapes. Prevalent part of the production consists of the production of extraction for the production of lids and covers of cans. Three-piece cans (3P) consist of two lids and rounded covers. Two-piece cans (2P) consist of lid and the cover in the shape of extraction with a flange. Lids, as well as covers, are produced from tin coated and often from lacquered sheets. During drawing, there occur various stressdeformation states within the extraction. Biggest 
problem is tensile strain, which increases porosity of tin coated and also lacquered layer. Such an increase of porosity can cause problems during the long-term storing of groceries in metal packages. Problems consist in the fact that the contents of cans often function as an electrochemical solution (medium) and are the source of electrochemical corrosion. Porosity of protection layers increases in the areas with the largest plastic deformation. During drawing of thin steel sheets, such areas are the joint between the bottom of a lid and its wall and the joint between the bottom of a package and the cover of an extraction. In these areas, the deformation increases considerably, often it comes to the thinning of thin steel sheet and that is why the porosity of the tin and lacquer protection coating that occurs in these areas is the largest (Fig. 3).
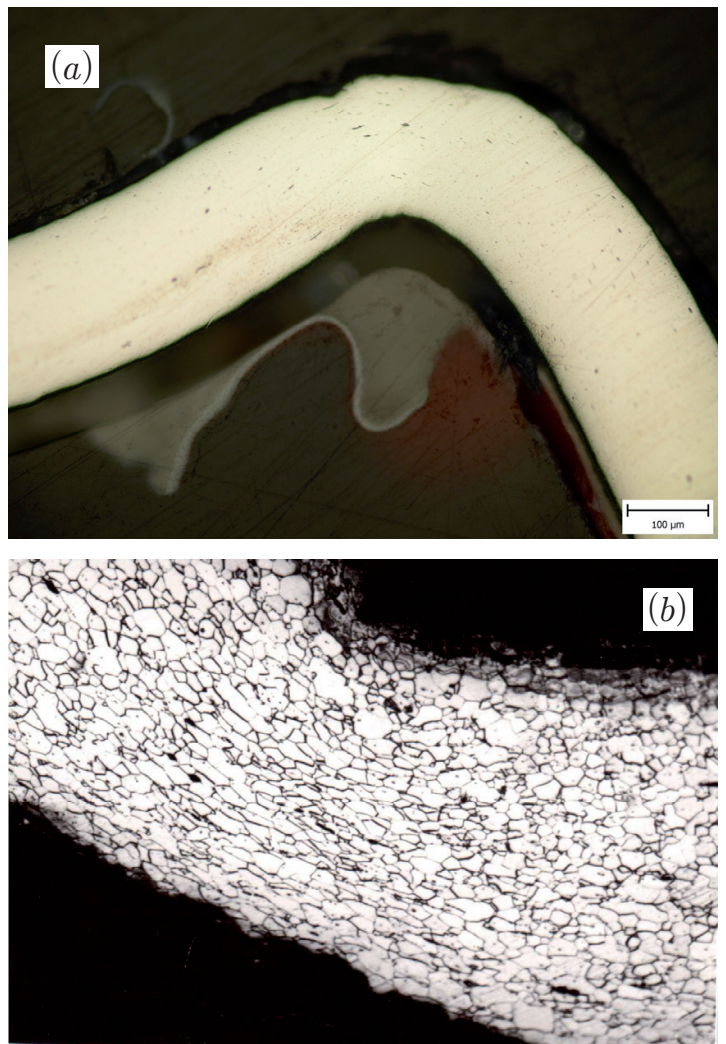

Fig. 3: (a) Local thinning on the lid. (b) Detail of the thinning.

Influence of the can content on the tin coated and lacquered sheet causes the beginning of corrosion in these areas. Corrosion appears gradually and it spreads from the inner surface (Fig. 4).

Fig. 5 shows a detail of such corrosion disruption of the thin steel packaging sheets. From the figure, it is apparent that the corrosion started on the protection tin layer and the lacquered layer and then it progressed throughout the whole cross-section. In the Fig 5 a), it is visible that the corrosion progressed only in the area of thickness, in the remaining part, the can got disrupted by the pressure beginning from the change of temperature of the can content (during the change of storing conditions from $6^{\circ} \mathrm{C}$ down to circa $-25^{\circ} \mathrm{C}$ ). In the Fig. 5 b), we can see that the corrosion progressed throughout the crosssection of steel sheet and next to the corrosion disruption there was another large corrosion area.
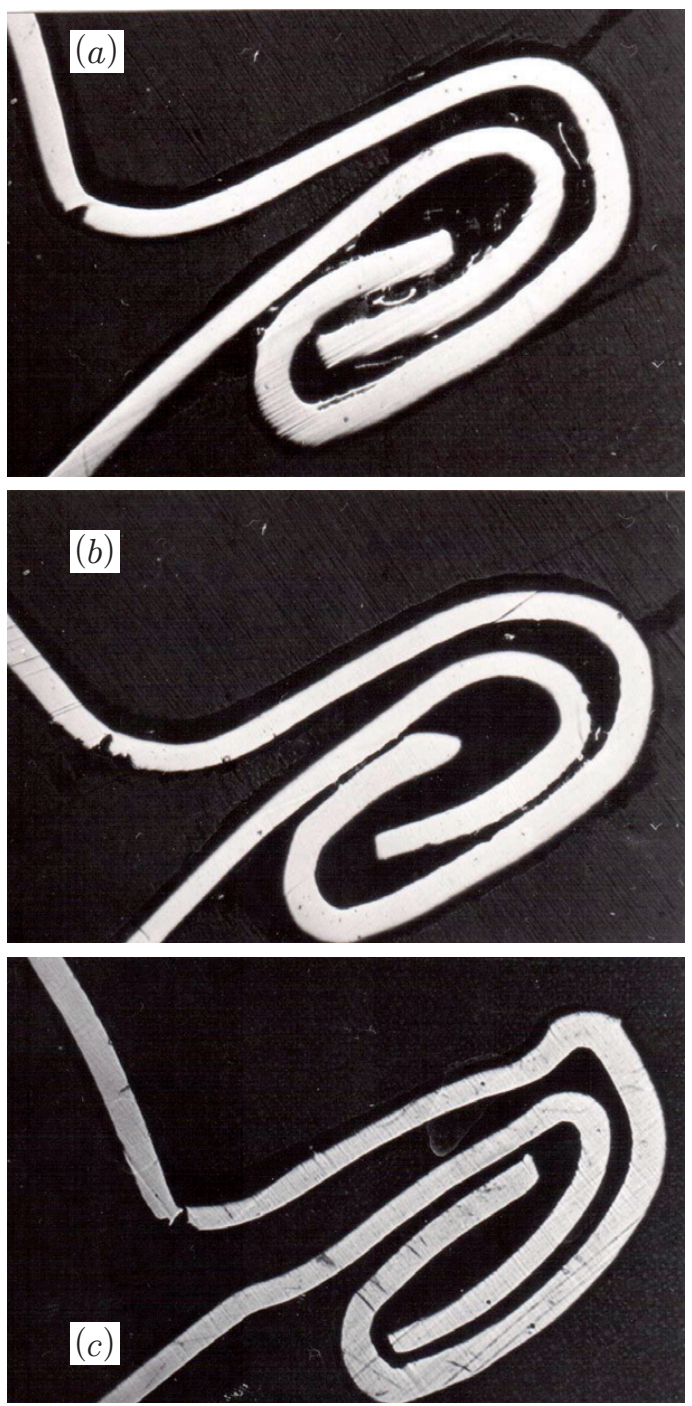

Fig. 4: Areas with the maximum deformation in the can, where corrosion starts to spread. (a) Beginning of corrosion. (b) Spreading of corrosion. (c) Complete corrosion of steel sheet. 

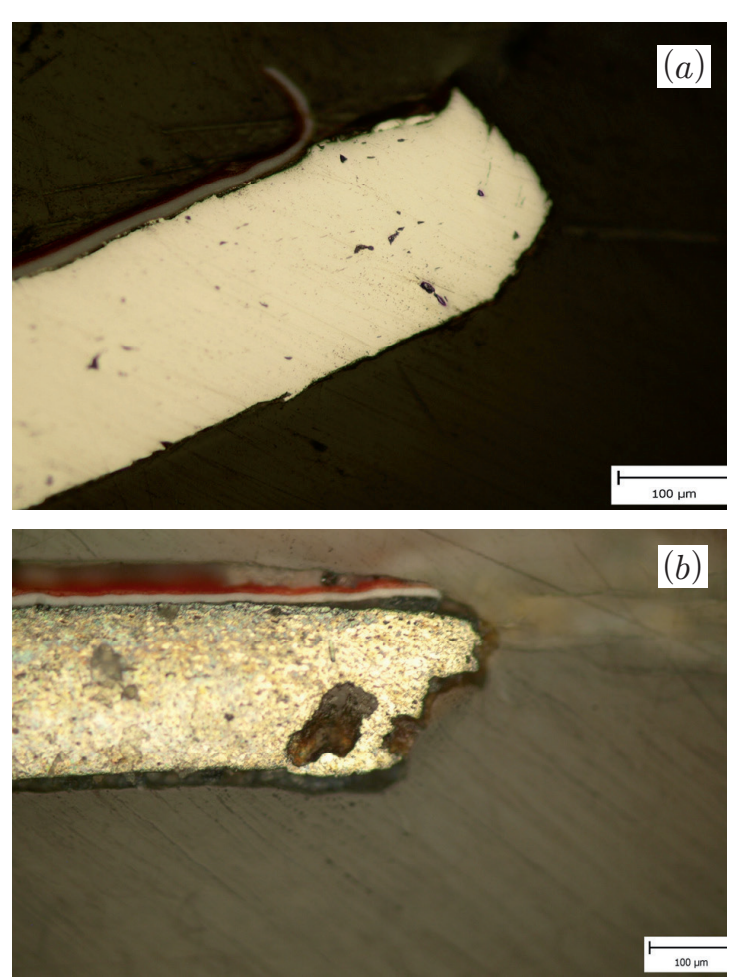

Fig. 5: Disruption of the protection tin layer. (a) Corrosion progressed only in the area of thickness. (b) Corrosion progressed throughout the cross-section of steel sheet.

In the Fig. 6, it is possible to observe the types of corrosion of thin steel sheets, which content is made up of meat mixture. In these cases, corrosion appeared already after several months of storing of the cans (8-12 months) and the increased content of salt for the conservation of the can content is considered to be the major cause for the corrosion. In these cases, corrosion progressed gradually right under the tin layer and then it spread rapidly throughout the entire cross-section.

Areas with a beginning corrosion are presented in the Fig. 7. In this case, packaging sheet was tincoated (thickness of tin-coating $-1.1 \mathrm{~g} / \mathrm{m}^{2}$ ) and subsequently lacquered (thickness of lacquer 2 $3 \mu \mathrm{m}$ ). In the areas of beginning corrosion (Fig. 7a), we can observe the fact that the corrosion begins in relation to the size and orientation of grains of steel sheet.

Based on the examined packages, we stated the fact that corrosion appears in the areas with no considerable deformation of packaging sheet. Area like that can often is the middle part of a lid or a so called twist lid (locking lid). In these cases, corrosion
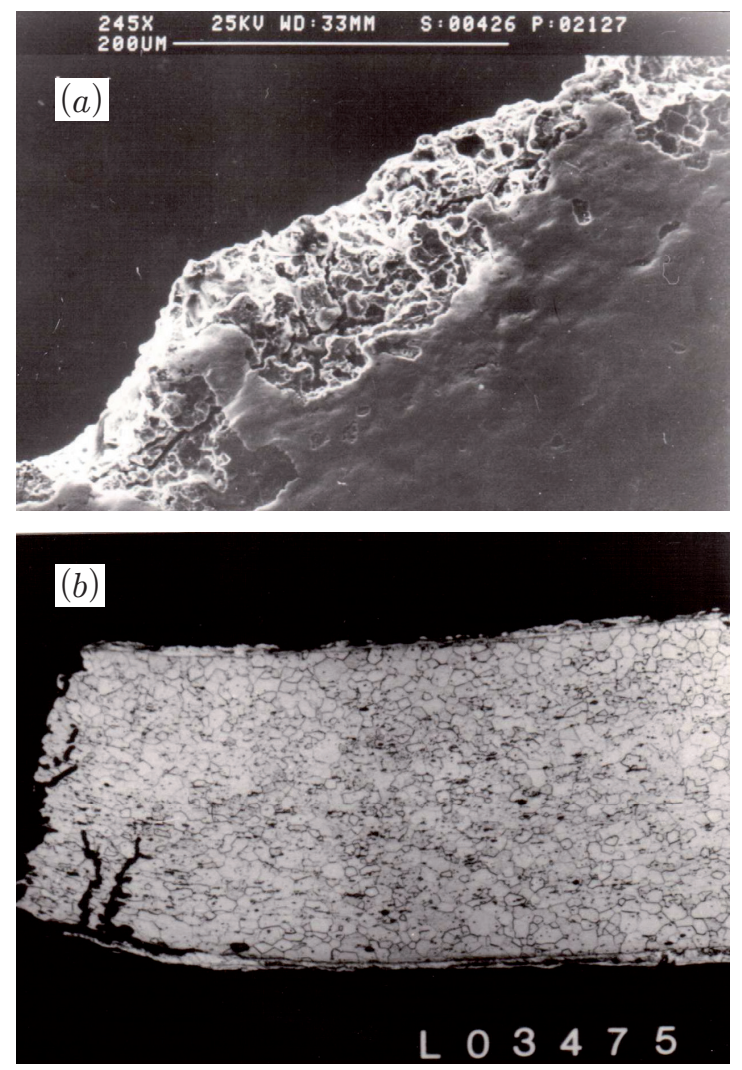

Fig. 6: Areas with the local corrosion gradually spreading through the entire thickness of material. (a) Corrosion on the surface of a can lid. (b) Cut in the area of corrosion with the visible secondary areas of corrosion.

begins in the areas with the various impurities beneath the tin coating in the steel sheet. Such impurities rights beneath the surface are presented in the Fig. 8.

During all the above mentioned and described processes of corrosion, corrosion waste products cause contamination of the can contents. Speed of the progression and the extent of corrosion are influenced by the size of plastic deformation in the particular area, porosity of tin and lacquer surface, and the corrosion aggressiveness of the can content. During the production of can lids and so called twist lids, it is necessary to be aware of the fact that higher the plastic deformation is in the local area the more possible it is for the corrosion to begin in that area, because of the decrease of corrosion resistance of the protection coatings.

\section{Conclusions}

Steel sheet of this thickness used for the 

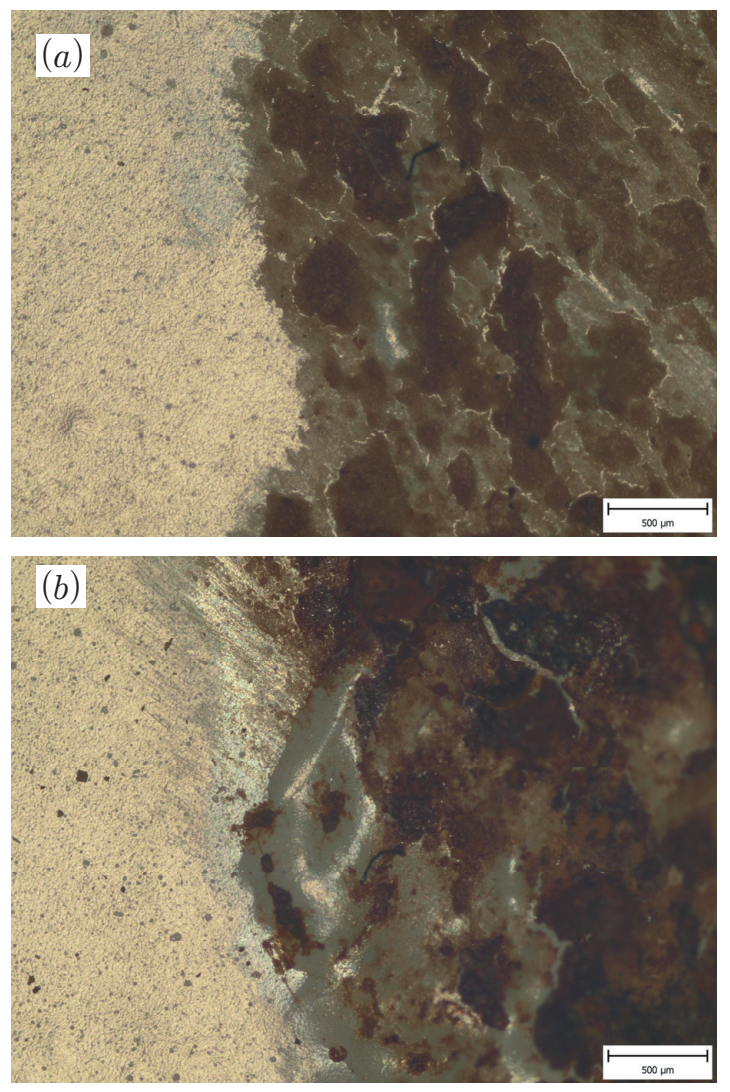

Fig. 7: Areas with the beginning surface corrosion of the thin tincoated and lacquered packaging sheets. (a) Surface corrosion in the earlier stage. (b) Corrosion in the later stage.

production of packages is easily collected and separated and can be re-used as an iron-scrap (scrap metal) in the furnaces for the steel production. Steel sheet and the packages made from it are quite environmentally friendly even in the case where they are left in the nature and not returned to the steel mill. Thin packaging sheet, currently used for the production of packages, corrodes for a couple of years in the regular natural environment (before it is decomposing completely). Separation of currently more preferred plastic packages or packagings made from composite materials is considerably more complicated. Many of them are inseparable (separation of individual compounds within one material is too expensive) and that is why they are being burnt which is source of emissions. If these non-metal materials are not properly collected, they end up as garbage in nature and their decomposition takes decades and sometimes even hundreds of years.
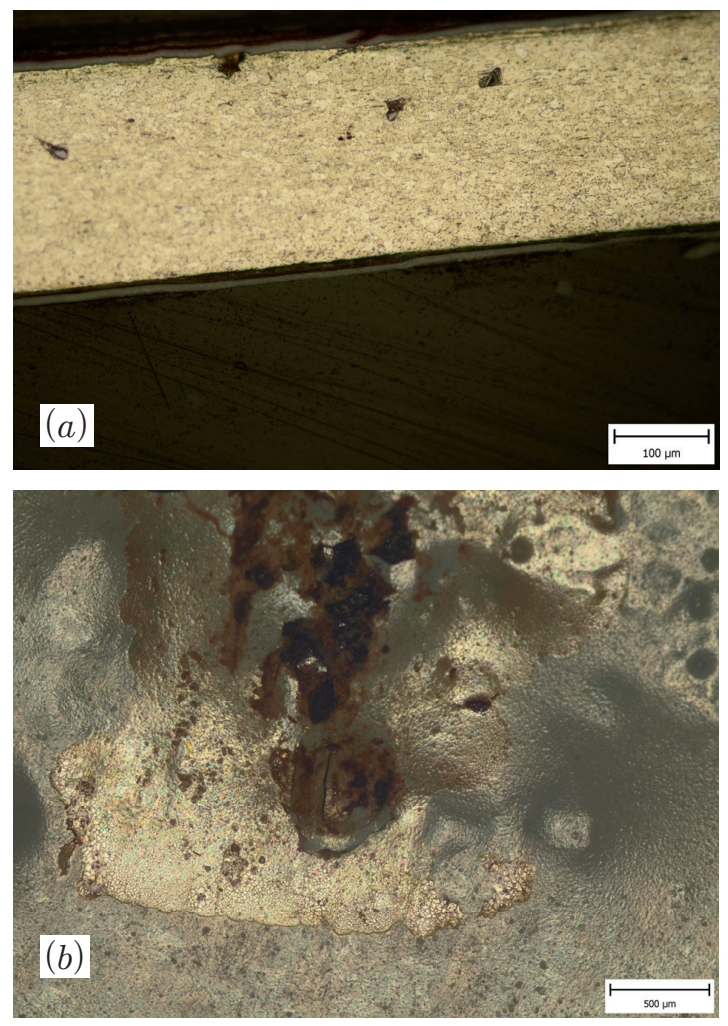

Fig. 8: (a) Impurities of steel that cause local corrosion right beneath the surface. (b) Impurities in the middle part of a lid.

Despite of all of the above mentioned problems with the corrosion, thin steel sheets are still a demanded packaging material. Corrosion of packages appears mainly during the use of the sheets with lower quality of packaging steel sheets and during the imprecise and incorrect technological production method of the can coatings and can lids production, and also during the incorrect closing of the cans.

Based on the above mentioned facts, we believe that packaging sheet still is and for many years will be not only economically but also ecologically convenient material for the production of packages, especially for the food industry, but also for the other branches of industry.

\section{Acknowledgments}

The authors are grateful to APVV for support of experimental work under grant APVV-14-0834 and VEGA 1/0441/17.

\section{References and Notes}

[1] Apeal. Oficiálna stránka asociácie európskych výrobcov ocele pre výrobu obalových materiálov. From http://www. apeal.org/en/apeal/who-we-are, 2012-05-19. 
[2] Machek, V., Tenké ocelové pásy a plechy valcované za studena, STNL - Nakladatelství technické literatury, Praha, 1987.

[3] Majerníková, J., Medzné deformácie tenkých obalových plechov pri rôznych napätovo-deformačných stavoch, Dizertačná práca, Košice, 2008.

[4] Majerníková, J., Spišák, E., Hodnotenie vlastností tenkých obalových kontinuálne a poklopovo žíhaných plechov pre obalový priemysel, Kovárenství, vol. 44, 2012, p. 45-48.

[5] Spišák, E., Majerníková, J., Analysis of variance of mechanical properties of sheets as the input parameters for simulation of processes, Acta Metallurgica Slovaca, vol. 18, no. 2-3, 2013, p. 109-116.

[6] U. S. Steel Košice, s.r.o. Výrobky obalovej vetvy. From http:// www.usske.sk/products/cat-s/tin-mill/index.html.mechanical, 2015-04-28

[7] Wang, X., Zhu, Z., Cai, F., Li, H., Effects of continuous annealing process on microstructure and properties of electrolytic tinplate, Heat Treatment of Metals, vol. 38, no. 6, 2013, p. 49-54

[8] Wang, B., Zhang, Q.D., Yu, M., Zhang, X.F., Ni, G.H., Description and Control of Tin Plate Surface Visual Quality, Advanced Materials Research, vol. 145, 2010, p. 510-515.

[9] World steel association. Oficiálna stránka zastrešujúca združenia popredných výrobcov ocele na svete. From http://www.worldsteel.org/, 2015-05-19.

[10] Spišák, E., Slota, J., Majerníková, J., The evaluation of mechanical properties of tinplates as input parameters for simulation of deep drawing processes, Metalurgija, vol. 49, no. 2, 2010, p. 528-532.

[11] Spišák, E., Majerníková, J., The Loss of Plastic Properties Stability of Thin Tinplates and Its Influence on Change of Corrosive Resistance, Applied Mechanics and Materials, vol. 693, 2014, p. 340-345.

[12] Spišák, E., Majerníková, J., Plastic properties of twice reduced packaging sheets, Hutnické listy, vol. 63, no. 4, 2010, p. 65 69.

[13] Spišák, E., Majerníková, J., Annealing process and its influence on mechanical properties of packaging sheets, Scientific Bulletins of Rzeszów University of Technology, no. 273, 2010, p. 235-242.

[14] Spišák, E., Majerníková, J., A Study of Thickness Change of Spherical Cup Made from TRIP Steel after Hydraulic Bulge Test, Key Engineering Materials, vol. 635, 2015, p. 157-160.

[15] Spišák, E., Slota, J., Majerníková, J., Analýza priebehu deformácie jednoducho a dvakrát redukovaných obalových plechov Chemické listy, vol. 105, no. S, 2011, p. 485-487.

[16] Spišák, E., Slota, J., Majerníková, J., Kašcák, L., Malega, P., Inhomogeneous plastic deformation of tinplates under uniaxial stress state, Chemické listy, vol. 106, no. S, 2012, p. 537-540.

[17] SSAB Hauptsitz. Oficiálna stránka spoločnosti. From http:// www.ssab.com/de/About-SSAB1/Steel-making-process/
Processing/Sheet-steel/, 2015-06-20.

\section{Biographical notes}

Prof. Ing. Emil Spišák, CSc., (born 1955) is professor of Department of Mechanical Engineering Technologies and Materials, Faculty of Mechanical Engineering, Technical University of Košice. He is head of the Department of Mechanical Engineering Technologies and Materials and Director of the Institute of Technology and Materials Engineering. He served as Vice-Dean for 6 years and Vice-Rector for 12 years. He works in the area of evaluation of material properties, material failures, analysis and quantification of production factors influence in production of thin steel sheet stamping parts, modelling and simulation of technological processes, mainly forming processes. He is national secretary and a member of International Deep-Drawing Research Group. He is author of 7 monographs and more than 573 publications (12 CC, 50 WOS, 78 SCOPUS) in journals and conference proceedings at Slovakia and abroad. His published works were cited 341 times. He has been worked on 64 grant projects, research tasks and 88 projects solved for industry.

Janka Majerníková, doc. Ing., PhD., (born 1966) is associated professor of Department of Mechanical Engineering Technologies and Materials, Faculty of Mechanical Engineering, Technical University of Košice. She is graduated on Faculty of Mechanical Engineering, Technical University of Košice, where she received also scientific degree PhD and where she habilitated at the field of production technologies. Her research works are mainly focused on the area of evaluating of material properties, materials failures and analysis and quantification of production factors influence in production of thin steel sheet stamping parts. She is an author of 8 university textbooks and more than 120 publications in journals and conference proceeding in Slovakia and abroad. She has been worked on several grant projects, research tasks and several projects solved for industry. 